\title{
Learning Environment for Second Language Acquisition: Through the Eyes of English Teachers in Thailand
}

\author{
P. Kiatkheeree
}

\begin{abstract}
Studying about learning environment to promote students' achievement has been widely discussed among scholars in the area of English as a second language. It is believed that suitable learning environment affects the overall academic success. This article revealed key factors affecting students' achievement in learning English through the eyes of classroom university teachers in Thai higher education institution. The study found that learning environment was affected by three aspects, namely physical environment, academic environment, and psychological environment. In addition, the findings revealed that physical environment is regarded as the most crucial factors to promote students' achievement. This study also provides implications for those who would like to promote and improve students' proficiency in learning English as a second language.
\end{abstract}

Index Terms-Learning environment, second language acquisition, students' achievement, Thai higher education institution.

\section{INTRODUCTION}

Learning environment has been widely discussed among scholars in the area of English as one of key factors in promoting students' achievement. According to the literature, learning environment is categorised into three broad aspects including physical environment (such as materials, building, or classroom), psychological environment (such as attitude and value), and academic environment (such as learning strategy or academic performance), and these affect the overall academic success in acquiring second language [1]-[4].

It is noted that a learning environment has significant effect on the level of language proficiency learners. For example, students and teachers interaction in a classroom, as part of learning environment, is regarded as important factor in promoting students' achievement [5]-[7]. Building effective learning environment seems to have great impact on second language learners. As English plays a crucial role in Thai higher education, there is also a demand for improving the quality of English language. However, the data reveals that Thai students have poor command of English with the lowest score of TOEFL among countries in Asian region [8], [9]. Therefore, investigating towards learning environment of English language learners is required. This paper seeks to identify and make a practical contribution to the literature of which factors promoting students' success in learning

Manuscript received June 26, 2017; revised September 14, 2017.

Parussaya Kiatkheeree is with Suratthani Rajabhat University, Thailand (e-mail: parussaya@hotmail.com).
English language through the eyes of the university classroom teachers. This led to the main research question that is "What is the effective learning environment in Thai EFL context?"

\section{REVIEW OF THE LITERATURE}

Promoting a second language acquisition requires several key components. Likewise, enhancing English language acquisition of learners is required many factors. One of crucial factors is learning environment. Learning environment is considered to be one of crucial factors promoting students' achievement. Many scholars have explained learning environment affect both physical and psychological conditions of second language learners. The literature indicates that learning environment can be categorised into three broad aspects: academic environment, physical environment, and psychological environment.

\section{A. English Language Education in Thailand}

There are a number of scholars identifying the importance of promoting English as a second language to students. Pica [10] claims that there should be an investigation into second language learning to promote second language learners' efficiency.

In the past two decades, education in Thailand, particularly English language education, has undergone radical change. Since Thailand education reform in 1999 Thai classroom context has shifted from teacher-centred to learner-centred approach.

English, in Thailand, is considered as the compulsory subject in all levels and accorded the highest status compared to other foreign languages [11], [12]. While there are many policies launched to support the English proficiency of Thai students, their English proficiency is still below standard [13].

\section{B. Learning Environment}

Regarding the academic environment, teachers are seen to be a key factor in promoting positive academic environment which includes their characteristics of having good knowledge of subject matter and spending sufficient time in teaching, including being a full-time teacher in a single-school [14]. These include their capable in creating effective classroom environment, understanding or the curriculum and its purpose, making changes in teaching and learning approaches, and reflecting on their teaching and their students' responses [14]-[18]. This is in accordance with [1], a positive academic environment includes good teaching, emphasis on independence, clear goals and standard, appropriate assessment, and appropriate workload. 
As classroom environment affects students' learning achievement, physical environment is seen to be one important factor in building good environment for learning. Physical environment includes all related things that human constructs including noise, crowding, housing and quality of neighbourhood [2], [3], [19]. Kopko [20], in addition, asserts that noise affects learners' reading abilities, cognitive development, physiological indicators, and motivational tasks. It is possible to say that maintain and providing appropriate environments are essential in promoting and motivating learners [15], [21].

It is indicated that the physical resources obviously influence students' achievement [19]. Therefore, students, teachers and all people involved in the educational system should be studied in order to gain insights into related learning environment factors in promoting effective classroom environment.

\section{Methodology}

\section{A. The Qualitative Research Paradigm of the Study}

In this investigation, a qualitative case study was chosen as the most suitable design to answer the research questions. By employing the case study approach, the researcher could interact with the real-life context and gain a deep understanding of cases [22]. Cases, in the current study, include a number of lecturers in one Thai higher education institution.

\section{B. The Research Context}

The context, a Thai higher education institution, was seen to be important as suggested by [23]. This provided the researcher understand information of the cases related to their historical background and physical settings. These several cases allow the researcher to gain in-depth understanding of a case including its context [24].

At the time of the study, the participating university was a public university located in the south of Thailand. As an independent university, the university has its own administrative system. The university focused to respond to local needs through a variety of programmes offered. The university offered both bachelor's and master's degrees in various fields. For bachelor's degree, it offered degrees in seven fields including education, humanities and social science, science and technology, management sciences, nursing, law, and international school of tourism. In addition, master's degrees were offered in the field of education, arts, business administration, science, public health, and public administration. In the past few years, the university also offered one $\mathrm{PhD}$ programme in education.

It is obvious that the university supports and encourages students to practice their English proficiency. The university itself sought to assist and promote local development. Variety of units was set up to assist both administrative and academic functions. The university set up academic units to promote students' English proficiency. One of the outstanding policies was the "TOEIC". The Test of English for International Communication (TOEIC) is an English language test to measure the everyday English skills designed based on real-life work settings in an international environment. This project had been promoted and run by the language centre. In accordance with the language policy, one important mission was about to promote English language of students. Therefore, the university set up academic units such as the language centre to support students' English proficiency. At the time of the study, the language centre had continually conducted both short and long English courses. In addition, the language centre was a centre not only for students and staff, but also other people who would like to increase their English proficiency.

The university also set up the language lounge to support students' English achievement. The language lounge is under the supervision of the Faculty of Humanities and Social Sciences. The language lounge was set up to serve students' self-learning to improve their English. However, there was only one language lounge available for students. Therefore, only English major students from the Faculty of Humanities and Social Sciences had priority to use the language lounge. It is meant that only around one-tenth of students were able to use the service. This issue was seen to affect the level of English proficiency and the positive attitude towards English of students.

\section{The Research Procedure}

The major technique to obtain data was semi-structured interviews. The researcher employing interview technique as this allowed the researcher to control the direction of interview and elicit more answers from the participants [25], [26]. The researcher also took notes in addition to audio-recording. The researcher collected data with the participating lecturers in Faculty of Education and Faculty of Humanities and Social Sciences.

To avoid any misunderstanding, all participants were interviewed in Thai and each participant was interviewed one time. The interviews were later translated into English. The interview questions included three broad aspects: physical, academic, and psychological factors relating to English teaching and learning environments.

\section{Ethical Consideration}

For ethical consideration, this research was conducted to comply four ethical issues namely respect for privacy and confidentiality, avoidance of conflict of interest, respect for truth, and minimising harm to avoid potential ethical problems which was seen relevant to any research study. Generally, privacy was protected by ensuring confidentiality of the identities of the participants. In addition, the researcher was not in a position to gain any financial incentives or in a position of responsibility over the participants. The researcher, importantly, reported what the data reveals. Also, the basic rights of the participants who involved in individual interviews were respected and the researcher ensured that there would be no physical and emotional risk to the participants.

\section{ANALYSIS AND INTERPRETATION}

The data obtained from this study was analysed following the three steps of data analysis as suggested by [24]. The data 
were analysed for significant themes. Then analysed data were integrated through cross-case analysis in which the researcher considered cases to see similarities and differences to form more general explanations. This was followed by looking for themes that cut across cases in each phase and across phases that shared similarities, differences, and looked for unique themes that emerged.

\section{RESULTS}

\section{A. Lecturer's View towards Learning Environment}

The interview data were obtained from the six lecturers teaching Basic English course. All of the participants were full-time academic staff members in the English Division from two faculties: Faculty of Humanities and Social Sciences and Faculty of Education. These six lecturers were females ranging in age from 29 to 40 years. Five participants held master's degrees in Teaching English and one participant held doctoral degree in English.

\section{Classroom Facility}

The participants appeared to have a similar view upon the classroom facility provided by the university. All participating lecturers were female and they had a teaching workload between $12-15$ hours per week. It was found that the university prepared basic classroom tools like chalk and talk which meant that each room was supplied only blackboard/ whiteboard and chalk (no whiteboard marker) and a projector. Lecturers involved in this study mentioned that classrooms were ranged in sizes random by the university registration office system. At the time of the interview, all lecturers had the similar size of room (45-50 students per room) with the basic classroom tools.

Lecturer: We are assigned to teach the course and the room is arranged by the registration system, these include four sound lab rooms.

Interviewer: What about your classroom?

Lecturer: My classroom is like normal one, only blackboard and a projector. I did not get the sound lab room.

As the lecturer mentioned about the sound lab rooms which were seen to be not enough for the vast number of students enrolled in the Basic English in each semester, the interviewer asked for further explanation about its facility.

The lecturer replied: "Sound labs are equipped with "Classware" which facilitates English learning. One of the English supplementary materials the university provided for students who enrolled in Basic English was a classware named Speexx. This Speexx is an online tool designed to improve four skills. According to the interviews, students who enrolled in the course are required to spend 50 hours on Speexx. Students will get password to login and this programme consists of 24 lessons starting from elementary to advanced level. And at the end of each lesson, there will be a test. The university also provided a sound system, computer, English programme. However, as it was mentioned by the participating lecturers, it was found that classrooms were not appropriate for learning. One participating lecturer asserted: "The classroom that we normally use include only blackboard and a projector and some rooms are terribly poor equipped with broken fans, or sometimes a broken projector".

It seems that the lecturers paid attention to a projector in which they used to support teaching.

Interviewer: What do you normally use teaching tools in your classroom?

Lecturer: Let me explain, the Basic English course is a course comes with a classroom programme such as book and audio CD. And we must have a computer or at least an audio player in class.

Interviewer: That means you have to carry all those things?

Lecturer: Right. I want my students to listen to the native speaker's voice.

Interviewer: What would you carry?

Lecturer: I carry everything. Sometimes the projector in the classroom is not working, so I have to change the room and this process takes time, actually waste a lot of time.

Interviewer: Does anyone fix the projector?

Lecturer: Actually we have the technical staff in each building. But for my case, the projector is totally broken so I have to change the room for the whole semester.

The results of this study indicate that classrooms were not appropriate in teaching English while the lecturers were responsible to provide necessary teaching tools to support their own teaching. According to one participating lecturer, finding new classroom was born to be her own duty while the registration office which arranged the room could not facilitate her. While the room facility was not suitable for teaching, participating lecturers employed ICT to support their teaching outside the classroom. For example, one lecturer advised students through Facebook or another used Line to inform about teaching contents.

\section{B. Lecturers' Characteristics}

According to the preliminary data, students mentioned about lecturers' characteristics including the need for foreign lecturers, the data obtained from the participants revealed that there were opposite perceptions towards lecturers' characteristics.

It appeared that lecturers viewed their own teaching characteristics affected students' English proficiency. One lecturer mentioned: "I will make them feel relaxed, encourage them to use English without feeling that English is difficult". Another lecturer noted: "I will be kind to them and pay attention to what they ask about English both inside and outside the classroom". It appeared that the participating lecturers encouraged students to study in a relaxed atmosphere. Surprisingly, it is believed that being a Thai lecturer teaching English encouraged students to learn more.

Lecturer: Students told me that they love to study with me because they understand what I have said.

Interviewer: Which language do you speak in class?

Lecturer: I speak English and students understand my English. However, they told me that they did not understand what foreign lecturers talk to them.

As it seemed students preferred Thai lecturers in studying Basic English, the participating lecturers also asserted that there were problems between foreign lecturers and students.

Lecturer: Foreign lecturers are way too much serious.

Interviewer: What do you mean, by the way they teach or their behaviour? 
Lecturer: Um. They are so strict and some students feel the lecturers are not treating them well in the classroom.

Interviewer: Is that a serious issue?

Lecturer: Yes, students were told to drop out from the course. When asked, they told us that that foreign lecturer forced them to do that.

The participating lecturers mentioned that students tend to study with Thai lecturers rather than with foreign lecturers. Importantly, there was no drop-out in Thai lecturers' classes relating to problems with lecturers. The participating lecturers were likely to believe that their own characteristics, especially being a Thai lecturer were suitable and met the expectation of students. Moreover, they gained privileged of being Thai as students felt comfortable and relaxed to ask more questions.

It is interesting that lecturers involved in this study felt their teaching techniques and classroom management were well supported specifically by the head of the course programme while they gained less materials supported from the university. In general, Basic English course was run under the registration office in which one academic staff led the entire course as the team leader. All lecturers teaching Basic English course must be under the supervision of the head of Basic English and they all shared course programme and materials including teaching techniques. The data revealed that lecturers teaching Basic English had positive attitude towards the course programme and they believed this course was managed suitably by means to promote English proficiency of students.

\section{Lecturers' Personality}

The preliminary data appeared to indicate that students had some problems with some lecturers, specifically foreign lecturers. The participating lecturers also noted these problems as it appeared to affect students' motivation in learning English. It is somewhat surprising to note that the lecturers stated problems students had with some foreign lecturers.

Lecturer: Students tend to drop out when they know they have to study with foreign lecturers. Actually I would be happy if this course [Basic English] taught by only Thai lecturers.

Interviewer: What do you mean? Do you have any criteria in selecting the lecturers?

Lecturer: First it is about basic English but students think it is difficult when they see foreign lecturers. Therefore, first groups of lecturers who teach this course are Thai. Unless there are no more Thai lecturers, foreign lecturers will be assigned to teach the course. However, recently one class taught by foreign lecturer, most of students drop out because they feel struggle with that foreign lecturer's personality... This is not what we want. We want students to feel happy and motivated to learn English.

From the interview, the university provided a lot of activities for students which sometimes affected classroom time. This changing of time affected some classes taught by foreign lecturers because they did not know how to contact a class with various groups of students. At the same time, students did not feel comfortable to speak to foreign lecturers.
Importantly, the university mission was to not only improve students' English proficiency, but promote good attitude and personality based on Thai tradition and integrate these into every basic course. So it is claimed that English should be integrated with the local context and this might explain why there was a case of students drop out of the course taught by foreign lecturers.

\section{DisCUSSIONS AND CONCLUSIONS}

The interview was conducted with a number of English lecturers in order to gain insights into the learning environment of students in Thai higher institution. It can be seen that the participating university had place an importance on promoting and improving English language skill of students. In addition, the university also supported each faculty to encourage students to improve their English proficiency. Despite the limited of classes using English as a medium of instruction, the university encouraged students to participate in English activities monitored by the lecturers, for example students were assigned to use online tool, attend a sound lab or join a language lounge.

It is obvious that classroom is considered to be a key factor in promoting positive learning atmosphere [3], [19]. It is interesting to note that lecturers placed an importance of classroom despite the fact that the university could not provide the classrooms that meet the need of lecturers. Lecturers mentioned the lack of appropriate classroom for online learning. They believed that English was a skilled subject which required learning materials including online learning tools. Moreover, normal classrooms were not suitable for improving and encouraging learning while a sound lab room, a well-equipped room for English course, was limited (only three sound lab rooms). The inappropriate might affect students' learning as learning environment that promotes English learning should be in a good repair [15], [21].

It has been indicated that the Basic English course was offered to students under the supervision of the head of course who monitored and managed classroom materials. At the same time, voices of lecturers teaching in the course were also emphasised. Meeting between the head and lecturers, and among lecturers were held to discuss and share their teaching and problems they experienced in the classroom. This kind of collaboration promoted effective classroom management and lecturers understood how to employ teaching tools and materials in the class.

The data indicated that lecturers were not overloaded with the workload as they had a workload between 12-15 hours. Moreover, they were under the supervision of the head of course with a clear and focused instruction and frequent monitoring. They agreed that they had a well-managed monitoring. This finding is in accordance with the previous literature indicating that appropriate workload and frequent monitoring and assessment are related [14], [15].

It is likely that students gained positive academic support such as good material and online tools. As lecturers asserted that they carefully selected and employed textbook and online tools to enhance English proficiency of students.

One important finding is that participating lecturers 
addressed the problems students encountered with the foreign lecturers. In addition, they noted that foreign lecturers might not be a suitable choice for Basic English course as they could not integrate Thai tradition and culture into learning while their personality were seen to obstruct a positive classroom environment.

The literature suggests that students' achievement is based on their value, culture, beliefs and perceptions [19]. However, lecturers' views were seen to affect the students' learning success. These different views of beliefs must be taken into account among lecturers to adjust their teaching to promote students' English achievement. In final consideration, it is recommended that the university itself needs to support and provide good classroom facility, ensures that lecturers are continually supported with appropriate workload, and emphasises teaching quality and promote effective activity and all related material and tools to build up desired learning environment.

\section{LIMITATIONS OF THE STUDY}

Due to the small sample size of participants involved in the study, the findings from this study might not represent the voice of all lecturers who get involved in the field of English within all Thai higher education institutions. In addition, participants were from one university, they may not represent the diversity of other higher education institutions in Thailand.

\section{ACKNOWLEDGEMENT}

This research was supported by the Institute of Research and Development at Suratthani Rajabhat University, Thailand.

\section{REFERENCES}

[1] A. Lizzio et al., "University students' perceptions of the learning environment and academic outcomes: Implications for theory and practice," Studies in Higher Education, vol. 27, no. 1, pp. 27-52, 2002.

[2] O. Prasitthirat, Study of Learning Environment of Students, Bangkok: Faculty of Education, Srinakharinwirot University, 1990.

[3] S. Sinthapanont, Learning Management: Focusing on Student-centred Approach of Basic Education, Bangkok: Aksorn Charoentat, 2002.

[4] V. Vidaček-Hainš et al., "Personal efficacy and factors of effective learning environment in higher education: Croatian and American students," JIOS, vol. 34, no. 1, pp. 153-158, 2010.

[5] T. M. Duffy et al., Designing Environments for Constructive Learning, Berlin: Springer-Verlag, 1993.

[6] M.-C. Opdenakkera and J. V. Dammea, "Teacher characteristics and teaching styles as effectiveness enhancing factors of classroom practice," Teaching and Teacher Education, vol. 22, pp. 1-21, 2006.

[7] E. M. V. Raaij and J. J. L. Schepers, "The acceptance and use of a virtual learning environment in China," Computers \& Education, vol. 50, pp. 838-952, 2008.

[8] Educational Testing Service. (2015). Test and score data summary for TOEFL Internet-based and paper-based tests between January -
December 2014. $\quad$ [Online]. Available: https://www.ets.org/s/toefl/pdf/94227_unlweb.pdf

[9] P. Punthumasen, "International program for teacher education: An approach to tackling problems of English education in Thailand," presented at the 11th UNESCO-APEID Internation Conference Reinventing Higher Education: Toward Participatory and Sustainable Development, Bangkok, Thailand, 2007.

[10] T. Pica, "Second language acquisition research and applied linguistics," Handbook of Research in Second Language Teaching and Learning, pp. 263-280, Mahway, N.J: L. Erlbaum Associates, 2005.

[11] K. Boonkit, Listening Strategies with Television Texts: A Study of Thai University Students of English as a Foreign Language, University of Tasmania, Tasmania, Australia. (2002),

[12] A. Wongsothorn et al., "English language teaching in Thailand today," Asia Pacific Journal of Education, vol. 22, no. 2, pp. 107-116, 2002.

[13] A. Wiriyachitra, "English language teaching and learning in Thailand in this decade," Thai TESOL Focus, vol. 15, no. 1, pp. 4-9, 2002.

[14] E. Leu. (2004). Developing a positive environment for teacher quality: Working paper \#3 under EQUIP1's study of school-based teacher inservice programs and clustering of schools. [Online]. Available: http://www.equip123.net/docs/Working-p3.pdf

[15] H. Craig et al., Teacher Development: Making an Impact, Washington DC: USAID and The World Bank, 1998.

[16] G. D. Fenstermacher and V. Richardson, On Making Determinations of Quality in Teaching, the Board on International Comparative Studies in Education of the National Academies/National Research Council, 2000.

[17] A. Lieberman, "Practices that support teacher development: Transforming conceptions of professional learning," Phi Delta Kappan, April 1995.

[18] M. T. Tatto, Teacher Quality and Development: Empirical Indicators and Methodological Issues in the Comparative Literature, the Board on International Comparative Studies in Education, National Academies/National Research Council, 2000.

[19] OECD. (2009). Creating effective teaching and learning environments: First result from TALIS. [Online]. Available: www.oecd.org/publishing/corrigenda

[20] K. Kopko. (2008). The effects of the physical environment on children's development. [Online]. Available: http://www.human.cornell.edu/hd/outreach-extension/upload/evans.p df

[21] M. Lockheed and A. Verspoor, Improving Primary Education in Developing Countries, New York: Oxford University Press, 1991.

[22] R. K. Yin, Applications of Case Study Research (3rd ed.), Los Angeles: Sage, 2012.

[23] D. M. Mertens, Research and Evaluation in Education and Psychology: Integrating Diversity with Quantitative, Qualitative, and Mixed Methods, (2nd ed.), Thousand Oaks, CA: Sage, 2005.

[24] M. B. Miles and A. M. Huberman, Qualitative Data Analysis: An Expanded Sourcebook, (2nd ed.), Thousand Oaks, CA: Sage, 1994.

[25] B. L. Berg, Qualitative Research Methods for the Social Sciences, (7th ed.), Boston: Allyn \& Bacon, 2009.

[26] J. McDonough and S. McDonough, Research Methods for English Language Teachers, London: Arnold, 1997.

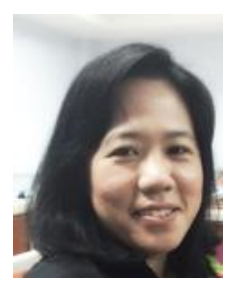

P. Kiatkheeree is a lecturer teaching English in the Faculty of Education at Suratthani Rajabhat University (SRU). She has an interest in enhancing professional development for academic and supporting staff. Her particular research focus is in the area of teaching English.

In addition, she is responsible for the master's degree programme in Teaching English for Academic and Occupational Purposes. Dr. Kiatkheeree holds a Ph.D. in Education from Massey University, New Zealand. 